\title{
Toplumsal Anımsamanın Millî Bayramlar ile Gerçekleşmesi: 23 Nisan Ulusal Egemenlik ve Çocuk Bayramı Örneği
}

\author{
Social Remembrance with National Holidays: The Case of April 23 National \\ Sovereignty and Children's Day
}

\author{
Doç. Dr. Mehmet Surur ÇELEPİ iD 1
}

\begin{abstract}
$\ddot{O} \mathbf{z}$
Bayramlar, toplumsal anımsamanın meydana geldiği önemli alanlardır. Aktarılan bilgi, deneyim ve geleneğin karşılığı olan kültürel bellek, bayramlar aracılığıyla geleceğe aktarılır. Bu aktarımda bayramların sahip oldukları işlevler toplumsal anımsamayı sağlar. 23 Nisan 1920'de TBMM'nin açılması uyanış hareketinin ve rejim değişikliğinin en önemli sembolüdür. Verilen mücadele ve meclisin kuruluşu bir sembolizm yaratır ve düşünceler sisteminin bir unsuru haline gelir. Bunun devamlılığı için de törenlerin kutlanması kararlaştırılır. Bu yüzden kuruluştan bir yıl sonra mücadeleyi meşrulaştırmaya yönelik olarak "Hâkimiyet-i Milliye Bayramı" adında bir millî bayramın kutlanması kararlaştırılır. Daha sonra 1917 yılında kurulan ve 1921 yılında da Ankara'da kurumsallaşan "Himaye-i Etfal Cemiyeti"nin çabalarıyla bu bayram çocuklarla anılmayan başlar. 1981 yılında da bugünkü 23 Nisan Ulusal Egemenlik ve Çocuk Bayramı" adına kavuşur. Bu bayram sahip olduğu politik işlevler, kültürün aktarımını sağlaması, kültürel ve toplumsal kimliklerin inşasına destek vermesi ve eğlendirme işlevi ile toplumsal anımsamayı sağlar. Millî iradeye meşruiyet kazandırması ve bu yolda verilen mücadelenin Türk çocuğuna anımsatılması bayramın politik işlevleridir. Bayramdaki icralar, Türk kültüründen taşıdığı izler, sürekli olarak "millî" değere yaptığı göndermeler, toprak ve vatan hassasiyeti, atalarla ilgili saygı tamamen Türklerin eski kültürlerindeki kült tasarımları ile ilgilidir. Bayramın sahip olduğu ortak simgesel sistemi kullanmak toplumsal kimliklerin inşasına destek olur. Okunan şiirler, düzenlenen yarışmalar, yapılan geçitler, sergilenen temsiller katılımcıların eğlenmelerini sağlar ve bir sonraki bayrama katılımcı sayısını artırır. Söz konusu bu işlevler toplumsal anımsamanın gerçekleşmesini sağlar.
\end{abstract}

Anahtar Kelimeler: Toplumsal anımsama, bayram, 23 Nisan Ulusal Egemenlik ve Çocuk Bayramı

Makale Türü: Araştırma

\begin{abstract}
Holidays are important for social remembrance to take place. The equivalent of the shared knowledge, experience and tradition -cultural memory is transferred to the future through holidays. In this transference context, the function of holidays is to provide social remembrance. The announcement of having established the Turkish Grand National Assembly on April 23, 1920 is the most important symbol of the independent movement. The struggle for independence and the establishment of the assembly create a potent symbol and become an element of the system of ideas. To provide continuance, it's decided to celebrate remembrance days. Therefore, one year after the establishment, it's decided to celebrate a national holiday called 'Turkish National Sovereignty' (Hâkimiyet-i Milliye Bayramı) to legitimize the struggle. With the efforts of the social services and child protection institution called "Himaye-i Etfal Cemiyeti", which was founded in 1917 and institutionalized in Ankara in 1921, this National Holiday begins to be attributed to
\end{abstract}

${ }^{1}$ Pamukkale Üniversitesi, Fen-Edebiyat Fakültesi, msururcelepi@ gmail.com.

Atıf için (to cite): Çelepi, M. S. (2020). Toplumsal anımsamanin millî bayramlar ile gerçekleşmesi: 23 Nisan Ulusal Egemenlik ve Çocuk Bayramı örneği. Afyon Kocatepe Üniversitesi Sosyal Bilimler Dergisi, 22(TBMM'nin 100. Yılı ve Millì İrade Özel Sayısı), $30-43$. 
children. Since 1981, it has been called April 23 National Sovereignty and Children's Day. With its political functions, cultural transmission, contributions for the construction of cultural and social identities, and entertainment features; this national holiday provides social remembrance. Giving legitimacy to the national will and reminding the struggle of independency to Turkish children are the political functions of the national holiday. The performance in the holiday, the motifs it carries from the Turkish culture, its constant references to the "national" value, the sensitivity of the land and homeland, the respect for the ancestors are all related to the cult designs of the ancient cultures of the Turks. Using the shared symbolic system that the national holiday has, contributes to the construction of social identities. The poems read, the competitions organized, the parades made, the performance exhibited provide the participants to have fun and increase the number of participants in the next holiday. These aforementioned functions enable social remembrance to take place.

Keywords: Social remembrance, holiday, April 23 National Sovereignty and Children's Day

Paper Type: Research

\section{Giriş}

2020 y1lı, 23 Nisan 1920 yılında ilan edilen millî iradeye dayalı rejime geçişin 100. yılıdır. Türkiye Cumhuriyeti'nin başlangıç simgesi olan TBMM'nin kuruluşu, Millî Mücadele için bir ivme kazandırmış ve beraberinde birçok kazanım getirmiştir. 100. yılında Anadolu Türkünün tarihî belleğinde önemli bir alanı olan millî iradenin başlama serüvenini unutmamak, hatırlamak, canlı tutmak ve bu çerçevede yüz yıl sonra bilimsel olarak çeşitli yönleriyle incelemek son derece önemlidir.

Birinci Dünya Savaşı'yla beraber Anadolu topraklarının bir kısmı işgal edilmiş ve toprakları paylaşma faaliyetleri hız kazanmıştır. Savaşın yarattı̆̆ tahribat bir yana, topraklarının yabancı devletlerce ele geçirilecek olması Anadolu insanında infial yaratmıştır. Savaşın sonunda vatan topraklarına düşmanın yerleşecek olması her ne kadar yıkıcı olsa da kendi içinde tekrar bir dirilişin başlangıcı olması açısından son derece önemlidir. Söz konusu diriliş Millî Mücadele adıyla başlamış, "Millı̂" kelimesinin anlam alanını doldururcasına topyekûn girişilen bir Kurtuluş Savaşı'na dönüşmüş ve dünya tarihinde özel bir yer oluşturmuştur (Çelepi, 2019, s.376). Bu süreçteki kazanımlara meşruiyet kazandırmak ve ileride anımsanmalarını sağlamak amacıyla çeşitli bayramların ve törenlerin düzenlenmesi kararlaştırılmıştır. Bu bağlamda TBMM'nin kuruluşu da millî bayram olarak kabul edilmiştir. Bu kabul edilişte bayramların, toplumsal anımsamadaki önemi ve toplumsal anımsamanın da uluslaşmadaki etkisi ön planda tutulmuştur.

$\mathrm{Bu}$ çalışmada millî bayramların önemi tartışılacak, ardından da 23 Nisan Ulusal Egemenlik ve Çocuk Bayramının toplumsal anımsamadaki önemi ve işlevleri incelenecektir. Konunun anlaşılması için öncelikle bellek-anımsama ilişkisi, bellek-anımsama türleri ve törenlerin önemi üzerinde durulmalıdır.

\section{Bellek ve Anımsama}

Bellek ve anımsama kavramları uzun bir süre tıp, biyoloji, psikoloji gibi bilimlerde bir anlam alanına sahip olduktan sonra, son asrın ikinci yarısından itibaren sosyal bilimlerin de ilgisini çekmeye başlamıştır. Söz konusu terimler farklı disiplinlerde birbirine yakın anlamlarda kullanılmaktadır. Türk Dil Kurumunun Güncel Türkçe Sözlüğünde bellek için "Yaşananları, öğrenilen konuları, bunların geçmişle ilişkisini bilinçli olarak zihinde saklama gücü, dağarcık, akıl, hafiza (Ar.)" tanımı yapılmaktadır. Yine Türk Dil Kurumunun Ruhbilim Terimleri sözlüğünde benzer tanımlara yer verilirken "anlıkta saklama gücü" ifadelerine yer verilmiştir. Belleğin eğitimle ilişkisinin yer verildiği Eğitim Terimleri Sözlüğünde "Algılanan nesnelerin ve yaşantıların bilinçte iz bırakması, saklanması ve gereğinde yeniden üretilmesi yeteneği" açıklamaları yer alır. Felsefe Terimleri sözlüğünde de benzer olarak "İzlenimleri, algıları vb. saklama ve yeniden bilinçte canlandırma yetisi” belleğin tanımı olarak kullanılır (https://sozluk.gov.tr). 
Bellek ile anılan "anımsama" için sözlüklerde farklı anlamlar olsa da kelimenin kökeni zihin anlamına gelen "an"dır. Anı ve anıt kelimeleri gibi anımsama kelimesi de "an"dan türemiştir. Anımsama için Ruhbilim Terimleri ve Eğitim Terimleri Sözlüklerinde "Önce öğrenilmiş ya da olmuş bir şeyi bellekte yeniden anma" şeklinde benzer tanıma yer verilir. Felsefe terimleri sözlüğünde anımsamanın "Platon felsefesinin çekirdek kavramı olduğu ve ruhun bedene girmeden önceki varlığında görmüş olduğu ideaların bilince dönüşü" tanımına yer verilirken bilgi öğretisi bakımından anımsamanı ruhbilimsel anımsama ile eşanlamlı olmadığı belirtilir. (https://sozluk.gov.tr).

Yukarıdaki açıklamalar bellek ve anımsamanın bireyle ilintili olduğu üzerine temellendirilmiştir. Bu iki kavramın bireyle ilintili olarak izahı, kavramların terim anlamlarının da bu çerçevede şekillenmesine neden olur. Bireyle anılan bellek ve anımsama, tarihî süreçte toplumlarla anılmaya başlar. Merkantilizm akımı ve evrildiği sömürgecilik, sömürgeciliğin esas nedenlerinden olduğu 1. Dünya savaşı, savaşın yarattı̆̆ 1 coğrafi ve bireysel travma neticesindeki yeni dünya düzeni gibi tarihî dönemeçler, milletlerin geçmişleri hakkında bilgi sahibi olmaları ihtiyaçlarını artırmıştır. Bu ihtiyaçla ilintili olarak bireyle anılan bellek ve anımsamanın toplumlara da uyarlanabileceği prensibi ortaya çıkmıştır. Zira bireyin anımsanan bir belleği varsa toplumların da anımsanan belleği olmalıdır. Bunun için de bireyin belleğini ve anılarını nasıl koruyup yeniden keşfettiği soruları, toplumların anılarını nasıl koruyup nasıl yeniden keşfettikleri ve ileriye nasıl aktardıkları şekline uyarlanır (Connerton, 2014, s. 67). Burada bireysel tecrübelerin toplumsal tecrübelere dönüşümü izlenir. Bu izlencede söz ve yazının farklılığ gereğince, yazının yaygınlaşması ile birlikte sözel belleğin ne kadarının yazıyla kayıt altına alındığı veya alınabileceği, aktarım süreci söz/yazı düalizmi üzerinden incelenmeye çalışılır.

Bellek ve anımsama kavramlarının anlam alanlarının genişlemesi ile birlikte semiyosferleri tartışılmaya başlamıştır. Bu çerçevede bireysel bellek, toplumsal/kolektif bellek ve kültürel bellek yaklaşımları doğmuştur. Üç yaklaşımda bireyin, toplumun ve kültürün belleğinin ne olduğu ve bireyin, insanların ve kültürün nasıl anımsadığı tartışılmıştır. Anımsamanın gerçekleşmesi için bir belleğe ihtiyaç vardır. Bireysel bellekte, bir gruba ait üyelerin birlikte yaşadığ deneyimlerin oluşturduğu anılar geçmiş düşüncesini belirler. Bireyin yaşadığ geçmiş, bireysel bellek fikrini oluştururken, birlikte yaşanan geçmiş kolektif belleği oluşturur (İlhan, 2018, s.29). Bireysel bellek anlaşılacağı üzere bireyin belleğine ilişkin içkin anılardan hareketle bir anımsama teorisi oluşturur. Yani kişisel bellek, konusunu bir kimsenin yaşam öyküsünden alan anımsama eylemleridir. Kişisel bir geçmiş içine yerleştirilmişlerdir ve kişisel bir geçmişe göndermede bulunurlar (Connerton, 2014, s. 42).

Toplumsal veya kolektif bellek yaklaşımı ise bir grup veya topluluk içinde oluşan anıların, yine o kolektif yapı içinde bulunulduğunda hatırlanacağını ileri sürer. Toplumsal bellek, onu taşıyanlarla birlikte vardır. Sürece katılanların grup üyeliğinin ispatıdır. Bu yüzden sadece somut mekân ve zaman değil, aynı zamanda somut kimliktir. Yani toplumsal bellek sadece gerçek ve yaşayan bir grupla ilişkilendirilebilir (Assmann, 2015, s. 48). Bu iki rakip kuram, belleğin içerikleri olan anıların "bireysel" veya "kolektif" olduğunu savunur. Bireysel ve kolektif belleğin ömrü birey veya grup ömrü kadardır. Toplumu organik bir bütün olarak gören, tüm bireylerin de bu organik bütünün bir parçası olduğunu, dolayısıyla bireyin tek başına bir hiç olduğunu düşünen sosyologlar kolektif bellek düşüncesine sarılırlar (İlhan 2018, s. 24-44). Bireysel bir belleğin oluşması ve korunması için sosyal çerçevenin şart olduğunu, bu çerçevenin dışında toplumda yaşayan insanların hatıralarını sabitleştirecekleri ve yeniden bulabilecekleri bir başka belleğin olmadığı, bu belleğin insanın sosyalizasyon sürecinde oluştuğu savunulur. Özetle, bellek insana ait olsa da toplumsal olarak belirlendiği ve bireylerin belleğini toplumla belirledikleri düşünülür (Assmann, 2015, s.44).

Bellek kavramıyla geliştirilen bir diğer kavram "kültürel bellek"tir. Bireysel ve toplumsal bellekten farklı olarak kültürel bellek, aktarılan bilgi, deneyim ve uygulamalarla ilgilidir. Kültürel bellek geleneğin karşılığı olarak kullanılır. Bir anlam aktarımı olan ve milletlere, tarihteki konumları ve dünya algıları hakkında ipuçları veren kültürel bellek ile insan belleğinin dış boyutu 
kastedilir. Kültürel belleğin neleri içerdiğini, bu içeriklerin organize edilişini ve ne kadar süre ile muhafaza edileceğini bireyin kapasitesi ve yöneliminden çok, dış koşullar, yani toplumsal ve kültürel çerçevenin koşulları belirler. Bu bellek kültüreldir, çünkü sadece kurumsal ve yapay olarak oluşturulabilir. Buna rağmen bellektir, çünkü toplumsal iletişimle ilişkisi, bireysel belleğin bilinçle ilişkisi ile aynıdır (Assmann 2015, s. 26-31).

Kültürel bellek, geçmişin belli noktalarına yönelse de değişiklilere ayak uydurarak her dönem yeniden kurulur. Daha çok anının bağlandığı sembolik figürlerde yoğunlaşır. Kültürel bellek için gerçek değil hatırlanan önemlidir. Geçmişle bağlantı kurularak hatırlayan grubun kimliği temellendirilir. Grup, tarihini hatırlayarak ve kökenine ait hatırlama figürlerini belleğinde canlandırarak kimliğinden emin olur (Assmann, 2015, s. 60- 61).

\section{Toplumsal Anımsama}

Belleğin ana malzemesi geçmiştir. Bellekte içkin olan geçmişi çağırma eylemi anımsama olarak adlandırılır. Bu bağ lamda bellek anımsamaya çalışmanın neticesi ve bu çabanın sonucudur. Bireyin geçmişini sakladığ 1 alan bireysel bellek olarak adlandırılmakta ve anımsama eylemi ile tekrar canlandırılarak anı/şimdiki zamanı şekillendirmekte ve anlamlı kılmaktadır. Birey, bu anlamlandırma çabasında sadece önemli olanı anımsar. Anımsadı̆̆ı, içselleştirilmiş olandır. Anımsama ile içselleştirilenlere yaşam şansı verilir.

Anımsama ile bireyin geri çağırdığı ve belirli alanlara işaret eden geçmiş, anı/hatıra olarak adlandırılabilir. $\mathrm{Bu}$, çok büyük ölçüde şimdiki zamandan ödünç alınan veriler yardımıyla yapılan, geçmişin bir yeniden inşasıdır. Ve bu yeniden inşa da zaten eskinin imgesinin epey değişmiş olarak yeniden çıktığı önceki zamanlara aittir (Halbbwachs, 2018, s. 66). Anıların saklanması için de yukarıda aktarıldığı üzere belleğe ihtiyaç vardır. Bellek, çoğu zaman tamamen bireysel, yani yalnız kendi kaynaklarına indirgenmiş, diğerlerinden izole ve önceden içinde bulunduğu durumları ya iradi olarak ya da şans eseri hatırlayabilen bir bilinçte ortaya çıkan bir yeti olarak değerlendirilir. Fakat bununla birlikte genellikle hafızanın ve hatıraların bir uzam ve zaman içerisinde diğerleriyle uzlaşılan kısımlara konulduğu ve onları sadece içerisinde yer alınılan gruplara göre bir anlamı olan tarihler arasına da yerleştirildiğini unutmamak gerekir (Halbwachs, 2018, s. 50).

Bireysel belleğin yanı sıra toplumsal ve kültürel belleğin olması, anımsamanın sadece bireye has bir eylem olmadığ 1 fikrini pekiştirir. Belleğin bir türü de kültürel olarak kabul ediliyorsa, kültürün yaşam alanı olan toplumun bu kültürü anımsaması gerekir. Birey, kendisinin ve etkileşim içinde olduğu grubun birikimini ve uygulayımını anımsıyorsa, toplum da ortak deneyim ve damıtılmışlıkla inşa ettiğini muhakkak anımsar. Yani anımsama hem bireyseldir hem de toplumsaldır. Yalnız burada terim karmaşasına düşmemek gerekir. Toplumun anımsadığı toplumsal bellek değil, kültürel bellektir. Zira ilk bölümde aktarıldığı üzere toplumsal/kolektif bellek toplumun belleği anlamına gelmez. Bireysel hatırlamanın sadece kolektif yapı içinde bulunulduğunda hatırlanacağını ileri sürer. Toplum belleğinin anlam alanı kültürel bellektir. Toplumsal anımsama kültürel hatırlamadır.

Toplumsal anımsamada kimin hatırladığından çok neyin hatırlandığı önemlidir. Böylece hatırlanan şeyin ne olduğu, geleneğin içeriğinin de ne olduğunu belirler. Hatırlanan şeyin ne olduğuna yönelecek bir hatırlama anlayışı da "kültürel bellek" kavramıyla karşılanabilecektir (İlhan 2018, s. 24). Toplumsal anımsamanın gerçekleşmesi hatırlama ve tekrarlama ile ilintilidir. Ortak anıları olan bir toplum, geçmişini kendine özgülüğü ve söz konusu anımsama ve tekrarlama ile korur (Assmann, 2015, s. 48). Kendine özgülüğün imgeleri bir araya gelince, o sirada var olan toplumsal düzeni meşru gösterirler. Herhangi bir toplumsal düzene katılmış bulunanların ortak anıları olduğunu varsaymaları gerektiği örtük bir kuraldır (Connerton, 2014, s. 11).

\section{Toplumsal Anımsama ve Bayramlar}

Bir topluluğun geçmişiyle ilgili en son unutacağ ş̧ey, belleğinde simgeleştirebilme yeti ve özelliği olan geçmişidir. Kültürel hafizada simgeleştirebilme özelliği en fazla olan alan da söz 
konusu topluluğun törenleridir. Milletlerin binlerce yıllık birikimlerinin neticesi olan, kültürün damıtılması ve kristalize edilmesiyle belirginleşen, geçmişi yaşatırken geleceği inşa eden törenleri, toplumsal anımsanın en etkin olduğu alanlarıdır. Söz konusu törenler, ortak bir deneyim ve tarihsel süreklilikle oluşturulmuşlardır ve dünyayı algılama, Tanrı'yla türlü şekillerde iletişime geçme, doğayla uyum içinde yaşama, belirli olay ve tarihleri anma, dinî hayatı yaşama ve hayatı devam ettirme faaliyetlerinin bir neticesidirler. Halk felsefesinin içselleştirilmesi ve ardından hayata tatbik edilmesiyle sistemli örüntülere dönüşen törenler, kültürel belleğin sürekliliğiyle devralınmışlardır (Çelepi, 2017, s.5)

Millet ve medeniyetlerin dünyayı algılamalarının ve tasarımlarının yansıması olarak grupla hareket etme, canlandırma, eğlenme, kaçınma, tapınma, yarışma, büyü gibi alanların birlikteliğiyle belirginleşen, bir araya gelmelerle yaşatılan ve süreklilik kazanan davranış kalıpları olan bu törenler kültürel anlam alanlarının en önemlileridirler. Törenlerin ortaya çıkışında, milletlerin doğaya karşı mücadeleleri, Tanrılar ve ruhlarla ilişkileri, tarım ve hayvancılık faaliyetleri, eğlenceleri, güzel sanatları, sözlü ve görsel icraları, takvim bilgileri, bereket anlayışları, beşeri ilişkileri, sporları etkilidir. Kadim kültürlerin izlerini yaşatan törenler, bir milletin ve medeniyetin kültürel örüntüsünün tümünün yer aldığı en büyük yapılardır. Törenler dışındaki hiçbir alan, bu kadar çok kültür ögesini kendi içerisinde barındırmaz (Çelepi, 2017, s.7).

Bir kültür dairesine bağlı olan insanlar, bu törenleri icra ederek ve katılarak hem kültürün sürekliliğine destek verirler hem de bu törenleri faaliyetlerine meşruiyet kazandıracak bir alan olarak kullanırlar. İcra tekrarlarıyla geçmişe yaşam şansı tanırken, aynı anda geleceği şekillendirirler. Böylelikle dünü ve bugünü birleştirerek kimlik sahibi olmada geçmişin yol haritalarını edinmeyi sağlarlar. Törenler böylelikle hem topluluğu hem de yaşanılan coğrafyayı kimlikli k1larlar.

Törenler, geçmişle ilişki kurma üzerine inşa edilirler. Geçmişle ilişki kurma, içinde bulunulan ânı anlamlı kılmanın yollarındandır. Geçmişle olan bağ, bir yandan tarihî belge ve bilgiler, diğer yandan akış halinde oluşturulan zihin kodlamalarıyla kurulur. Bu kurulum, insana evreni ve kendisini konumlandırma, anlamlandırma; ardından da belleğe kaydetme imkânı tanır. $\mathrm{Bu}$ kurulumla belirginleşen ortak belleğe ilişkin kodlar, törenlerin de içinde olduğu çeşitli hatırlamalarla ortaya çıkar (Arslan, 2017, s. 9).

Törenler, yalnızca olanı dillendirici nitelik taşımazlar. Araçsal eylemler olmaktan çok "dile getirici"dirler. Resmî biçimler almışlardır ve belirli bir biçeme bağlanma, basmakalıp biçimlere girme ve belli aralarla yinelenme eğilimi taşırlar. İçten gelen anlık zorlamalarla yürütülmezler; tersine belli duyguları dile getirmek için bilinçli olarak uygulanırlar (Connerton, 2014, s. 77).

Tören kavramının anlam alanı içinde bayramların önemli bir yeri vardır. Bayramlar, düzenli tekrarları ile kimliği koruyan bilginin iletilmesi ve devredilmesi, böylece kültürel kimliğin yeniden üretimini üstlenme işlevini yüklendiklerinden toplumsal anımsamanın en iyi gerçekleştiği alanlardır. Hangi şekilde kutlanırsa kutlansınlar, ortak yaşanan bir zamanı yansıtırlar (Assmann, 2015, s. 65). Bayramlar toplumun anımsaması için son derece önemlidirler. Çünkü bir tür simgesel kolektif metin ve temsil biçimi olarak toplumsal istikrarın ve dengenin nasıl kurulduğunu gösterirler (Connerton, 2014, s. 86).

\section{Türklerde Bayram ile Anımsama ve Millî Bayramlar}

Belirli bir zaman küçük gruplar halinde yaşayan insanlar, bir arada yaşamaya başladıktan sonra beliren güven ortamıyla işbölümü yaparak sorumluluklarını azaltırlar. Sosyal ve ekonomik açıdan rahat hayatın farkına vardıkça da bir araya gelip toplanmaya değer verirler. Bu toplantılar birçok işleve sahiptir. Bir arada yaşamak öncelikle doğanın yıkıcı gücünün azaltılması anlamına gelir. Bir araya gelmek ekonomik olarak iş bölümünün artması ve daha rahat hayat demektir. Belirli zamanlarda toplanmak sosyal hayatın düzene girmesini sağlar ve soyun devamı olan evlilikleri yaygınlaştırır. Dinî ritüellerin tekrarına imkân sağlar ve hayatın devamlılığına destek 
olur. Bir araya gelmek hep beraber eğlenme, yarışma, hoş vakit geçirme ortamı doğurur. Günlük hayatta yorulan bedenleri, karmaşıklaşan dimağları rahatlatmak, dinginleştirmek bu eğlence ortamları ve yarışmalarla mümkündür. Bu işlevlerin farkında olan insanlar, bütün bunlardan faydalanmak için sık sık bir araya gelerek bayram adını verdikleri törenler düzenlerler.

Toplumsal anımsanın en net teşekkül ettiği bayramlar, Türklerde Tanrı, ruh ve evren tasarımlarının yansımasıdır. Türkler, grup halinde yaşamanın gereği olarak bir araya geldikleri birçok durumda Tanrı ve ruhlarla sarmalanmış olduklarını düşünmüş ve her uygulamalarında Tanrıyı ve etraflarındaki ruhları takdis ederek mutlu etmeye çalışmış ve karşılığında da korunmayı, bereketin artmasını ummuşlardır. Türkler, bayram kelimesini çok geç kullanmış olsalar da kelimenin anlam alanının gereği olan bütün uygulamaları evren tasarımlarının gereği olarak çok eskiden beri yerine getirmişlerdir. Bunun karşıllı̆̆ olarak da semiyosferi çok geniş olan "toy" kelimesini kullanmışlardır. "Toy" kelimesi ilk başlarda "devlet yönetimi" ile ilgili kararların alındığı bir kurum hüviyetindedir. Devletin idaresiyle ilgili olan tahta çıkma törenleri, antlaşmalar, askerî toplantılar, av törenleri, ant törenleri, nüfus ve hayvan sayımı, çeşitli amaçlarla yapılan bütün toplantılar "devlet yönetimi" ile ilgiliydi ve söz konusu mecliste karara bağlanırlardı. Burada modern ülkelerde olduğu gibi bir meclis ve üyeleri vardı. "Toy" adlı mecliste alınan kararlar, daha sonra büyük ziyafetler ve eğlencelerle halka duyurulurdu. Kaşgarlı'nın ve diğerlerinin verdiği bilgiler, "Toy" kelimesinin ilerleyen zamanlarda "devlet meclisi" olarak sahip olduğu resmiliğini kaybetmeye başladığını ve sivil bir anlam kazanarak önce meclislerin ardından düzenlenen büyük ziyafetleri, eğlenceleri, dügünleri karşılayacak şekilde kullanıldığını, ardından da meclislerden sonra olmasa da büyük ziyafetleri karşılayacak şekilde kullanıldığını gösterir (Çelepi, 2017, ss.21-22).

Toy kelimesi ile bütüncül olarak karşılanan törenler zamanla resmilikten sivilliğe doğru ilerler. Bayramlar da bu törenlerdendir. Bayram kelimesinin Türkler arasında ne anlama geldiği hakkında Kaşgarlı Mahmud eserinde bilgiler verir. Bayram kelimesinin karşılığında "Bedhrem" kelimesini kullanır. "Bayram, halk arasında gülme ve sevinme. Bir yer ışıklarla ve çiçeklerle bezendiği zaman "bedhrem yer" denir ki "gönül açan yer demektir. Bu kelimenin aslının ne olduğunu bilmiyorum; çünkü bu kelimeyi Farslardan dahi işittim. Oğuzlar, bayram gününe "beyrem" derler. Bu sevinç ve eğlence günüdür." açıklamalarını yapar (DLT, I: 484). Kaşgarlı, "Bayram" kelimesinin sevinme, gülme, eğlenme anlamına geldiğini hatta bayram yerlerinin oluşturulduğunu açıklar. Anlaşıldığına göre Türklerde bayram, sevinme ve eğlenme günü olarak karş11ık bulmuş. "Beyrem" kelimesini açıklarken ise "Bunun, sevinç ve eğlence günü demek olan bedhrem kelimesinden bozulmuş olduğunu sanıyorum. Çünkü İslamlıktan evvel bayram bilmezlerdi ki adı olsun. Eğer olsaydı, bütün Türkler bilirdi” açıklamasını yapar (DLT, III: 176). Bedhrem kelimesinin geçtiği bir nazım parçasında da "Gençleri çalıştırarak, meyve toplatarak, kolan ve geyik avlatarak bayram yapıp avunalım, günlerce sevinç yaparak eğlenelim" açıklamalarını yapar (DLT, I: 263). Kaşgarlının açıklamalarına göre bayram kelimesinden daha çok sevinç, mutluluk ve eğlence anlamları çıkmaktadır. Kaşgarlının açıklamalarındaki diğer bir ayrıntı da bu eğlencelerin düzenlendiği yerlerin bayram yeri olarak adlandırılmasıdır. Anlaşılan bayramlar için özel yerler hazırlanmış. Türk kültüründen hareketle bayram yerlerinin dağ, orman veya nehir yakınlarında olduğunu tahmin etmek zor olmasa gerek.

Bayramlar, yurt ve sıla duygusuna sahip homojen bir topluluğun kendisi için üretilmek ve tüketim bakımından dışındakilere kapalı olmanın yanı sıra, kendi üyelerine anlamlı olmak ve kuşaklar arasında sözlü kültür ortamında aktarıla gelmek özelliklerine sahiptirler. Dahası geleneksel bayramlar kutlandıkları kültürün her çeşit geleneksel sanat ve oyun şeklini kendilerine ve kendilerini uygulayanların göreneklerine dayalı olarak muhteva, işlev ve biçim özellikleri üzerinde çeşitlenmeler meydana getirmek suretiyle kullanırlar. Kaynağını topluluk hayatından alan kolektif bir olgu olarak bayramlar, takvime bağlı günlerde topluluk tarafindan paylaşılan ve grup kimliğinin dışa vurulduğu çok amaçlı yahut çok işlevli ve karmaşık yapılara sahip kültürel formlardır (Çobanoğlu, 2000, ss.52-53). 
Bütün kavimlerde bayramlar, kutsal ve dönemsel olarak iki farklı zamana sahiptirler. Dönemsel bayramlar daha önemlidirler. Bu bayramlar bize kutsal olmayan ve akıp giden zamanı yıkma ve yeni bir zaman kurma isteğini bildirirler. Bir zaman dilimini kapatan ve başka bir zaman dilimini açan dönemsel bayramlar zamanın tamamen yenilenmesini sağlarlar (Eliade, 2015, s. 381). Bütün medeniyetlerde bayramlar anlam bakımından ikiye ayrıldıklarında; ilk bayramlar çıkış bakımından üretimle yakından ilgili olan bayramlar, ikinci ise ortaya çıkış bakımından belirli dinî inançlarla ilgili olan bayramlardır (Rahman, 1996, s. 120). Bu çerçevede Türk kavimlerinin bayram ve törenleri belirli tarihlerde yapılanlar ve bazı olaylar dolayısıyla (tarım, hayvanc1lık) yapılanlar olmak üzere ikiye ayrilabilir. Belirli tarihlerde yapılan bayramlar, ilkbahar, yaz ve güz mevsimlerinde yapılan ayinlerdir ki bunların çok eski devirlerden beri yapılmakta olduklarından şüphe yoktur.

Bayramların hükümdarların kontrolünde tertip edilmeleri ve kutlanmaları, bayramların resmî tarafıdır. Hükümdarlar dinî kurgudaki belirli tarihleri anmalarda, doğanın dengesiyle ilgili tarihlerde bayram tertip etmenin yanı sıra devlet işleyişiyle ilgili çeşitli durumlarda da bayram tertip ettirmiş ve halkı memnun etmeye çalışmıştır. Hükümdarın isteği ve kontrolü altındaki bayramlar tarihî süreçte çeşitlenmiş ve günümüze değin resmî bazı bayramların devlet ve yöneticilerin belirli olayları anma kararlılığ çerçevesinde kutlana gelmesine imkân sunmuştur. İlk başlarda hedefi doğanın ve soyun bereketini denetlemek ve olasılıkla topluluğun kendi tarihsel varlığını olumlamakla sınırlı olan bu törenler, giderek (saray-tapınak-karargah çerçevesinde odaklaşan) iktisadi-siyasal iktidarı, toplumun tümüne benimsetmede inanış sistemindeki değişikliklere eşlik eden ve iktidarın göksel kaynaklarını vurgulayan bir aygıta dönüşür (Özbudun, 1997, s. 12). Bu dönüşümde bayrak, millî marş, millî kahramanlar gibi yeni semboller üretilerek, laik bir yapı ile yeni törenler oluşmaya başlamıştır. Böylelikle yeni bir mazi oluşturma çabası başlamıştır (Bolat, 2012, s. 7).

$\mathrm{Bu}$ çerçevede ulus veya millî bayramlar ortaya çıkmıştır. Bütün varoluşları aynı anda değişime uğratan ulusal olaylar vardır (Halbwachs, 2018, s. 74). Varoluş mücadeleleri, rejim değişiklikleri, büyük kitlesel olaylar, uyanış hareketleri bu ulusal olaylardandır. Bu ulusal olaylar ve neticeleri bellekte bir alana sahip olurlar. Bu açıdan bakıldığında kültürel bayramlardan farklı olarak siyasal iktidarların kurguladığı ve salık verdiği millî bayramlar, olayların neticesi olarak kutlana gelirler. Belirli bir yapının ve ideolojinin hâkim olmasının ve buna süreklilik kazandırma arzusunun neticesidirler. Ulusal olaylar sonrasında ortaya çıkan yeni düzen, bu bayramları ihtiyaç hissedilen ruhun devamlılı̆g 1 için kullanır. Olayın anımsanması, belirli ritüel tekrarın varlığına muhtaçtır. Ritüel tekrar içerisine yerleştirilen kahramana, zamana, mekâna bağlı canlandırma sembolleri birer hatırlama figürüne dönüşerek bayramı anlamlı kılar. Bu tekrarlar yaşanılan anı anlamlı kılmak için görev üstlenirler.

Bayramların nasıl ve ne zamandan itibaren kutlandığını bilmek çok önemlidir. Ülkelerin tarihsel olarak geçirdikleri evreler ve önemli günleri o ülkelerin millî bayramları olmuştur. Türkiye'de de özellikle Millî Mücadele dönemi olayları millî günleri oluşturmuştur. (Bolat, 2012, s. 37). Fakat bir kavram olarak Millî Bayram ilk olarak Osmanlı İmparatorluğunun güç kaybı yaşadığı II. Meşrutiyetin ilanıyla ortaya çıkar. II. Meşrutiyet ile çeşitli fikir akımlarının önü açılmıştır. Bu hareketin önemli özelliği bu fikir akımlarından olan Türk Milliyetçiliğinin uyanması ve gelişmesidir. Bu fikirdekilerin, milletin katılacağı, heyecan duyacağı, sürekli hale getirip sonraki nesillere aktarma yoluyla, millî duyguları hep canlı tutabileceği önemli çabalardan birisi de millî bayramlar olmuştur (Bolat, 2012, s.24-25). İşte millî bayramların temeli, 23 Temmuz 1909 tarihinde atılır ve bu tarih millî bayram olarak kutlanmaya başlar. Millî bayram olgusu bu vesile ile resmî kimlik kazanmıştır. II. Meşrutiyet'e kadar geleneksel dini bayramların hüküm sürdüğü ve padişahın güç gösterilerine sahne olan meşruiyet zemini, yerini, halkın yönetime sınırlı da olsa katıldığ 1 günün kutlanmasına bırakmış ve adına da Hürriyet Bayramı denmiştir (Saban, 2019, s. 3).

Birinci Dünya Savaşı, savaşta Osmanlının içinde olduğu durum, savaşın sonlarına doğru başlayan direniş mücadelesi, yeni kahramanların ortaya çıkışı yeni bir Türk dünyası ve Türkiye 
hikâyesi oluşturur. Bu hikâyedeki Kurtuluş Mücadelesi ve kazanılmasındaki önemli anlar, mücadelenin kazanılmasıyla başlayan rejim değişiklikleri, reformlar ve kazanımların bazıları ayrı birer millî bayramın hikâyesini oluşturur. Mustafa Kemal Atatürk de bayramların hatırlama ve birleştiricilik işlevleri çerçevesinde Türkiye Cumhuriyetinin kazanımlarının hatırlanması ve sürekliliği için her kazanımdan sonra bir millî bayram belirlenmesini istemiş ve hayatta olduğu sürece de bayramlara ev sahipliği yapmaya çalışmıştır.

\section{23 Nisan Ulusal Egemenlik ve Çocuk Bayramı ve Toplumsal Anımsama}

1918'de sona eren Birinci Dünya Savaşı dünyada yeni bir düzen oluşturur. Bu düzen Osmanlı gibi devletleri daha çok etkiler. Osmanlı'nın toprak kaybetmesi, aynı zamanda yüzlere yılda inşa edilmiş olan mekân, insan ve bellek ilişkisinde değişimlere sebep olur. Çünkü fethedilen yerler sadece bir toprak parçası olarak görülmemiş oralarda girişilen inşa faaliyetleri kültürel inşayı da içermiştir. Balkanlar ve Ortadoğu savaşın öncesinde ve savaşın neticesi olarak Osmanlıdan teker teker ayrılmıştır. 1918'den sonra Mustafa Kemal ATATÜRK ve ona inananlar bir ulusal uyanış hareketi başlatırlar. Bu ulusal uyanış hareketi, hızla karşılık bulur. Çünkü tüm ulusal uyanış hareketleri, "yabancı boyunduruğunun" kırılması gereken bir özgürlük ve bağımsızlık zamanının mücadelesinden beslenirler (Assmann, 2015, s. 91).

Kurtuluş Mücadelesi ile elde edilen başarıların devamlılığı için de siyasal iktidar tarafından törenler düzenlenmeye başlanır. Siyasal iktidar, en geniş şekliyle bir toplumsal kesimin, toplumun bütünü üzerinde kurumsallaşmış yaptırım gücü olarak tanımlanabilir. Siyasal iktidarın meşruluğunun kurumsallaşması bir ucunda zorun, diğer ucundaysa ideolojinin yer aldığ 1 ve her tikel topluluğun devletleşme sürecinde kendi özgül dinamikleri çerçevesinde işleyen karmaşık ve çok yönlü bir ikna sürecidir (Özbudun, 1997, s. 58-59). Bu ikna sürecinde törenler bir gereksinim olarak ortaya çıkarlar. Bu gereksinim çerçevesinde kutlanması kararlaştırılan törenlerden biri de ulusal direnişin ve uyanışın sembolü olan Türkiye Büyük Millet Meclisinin kuruluşu ve kurulduğu tarih olan 23 Nisan 1920'dir.

Varlık süresi herhangi bir bireyin yaşam süresini aşan bir toplumsal grubun, topluca "anımsama" gücüne sahip olduğunu kabul ediyorsak, yalnızca söz konusu topluluğun, herhangi bir verili zamanda onu oluşturan çeşitli üyelerinin, grubun geçmişi ile ilgili şeylerin izlerini (zihinsel temsillerini) kafalarında tutabileceklerini söylemek yeterli değildir. Aynı zamanda grubun yaşlı üyelerinin, bu izleri grubun genç üyelerine aktarmayı boşlamamış olmaları da gerekir (Connerton, 2014, s. 68). Kurtuluş mücadelesini kazanan ve Cumhuriyeti inşa edenlerin de söz konusu kazanımları genç kuşaklara aktarabilmek amacıyla ilk kurguladıkları törenlerin başında TBMM'nin kuruluşunu anmak gelir.

Uyanış hareketinin ve dış dünyaya rejim değişikliğine gidileceğinin ilk ve en önemli sembolü TBMM'dir. TBMM'nin bir sembol haline gelmesinin siyasi nedenlerinin yanı sira anlamlı bir gerçekle zenginleşmiş olması son derece önemlidir. Verilen mücadele ve meclisin kuruluş aşaması bir sembolizm yaratır ve düşünceler sisteminin bir unsuru haline gelir. Bunun devamlılı̆̆ için de resmî törenlerin kutlanması kararlaştırılır. Bu resmî törenler, bir bakıma Cumhuriyet rejiminin "ideal toplumu" arasındaki dengelerin sergilendiği bir sahnedir. Bir araç olarak, yönetici-yönetilen ayırımının kurumsallaştığı, hiyerarşik ve siyasal iktidarın konumunu meşrulaştırmaya hizmet ederler (Özbudun, 1997, s. 159).

Ulusal bayramlar siyasal iktidarlar tarafından bir meşrulaştırma aracı olarak kullanılırken, muhalefette olanlar için durum biraz farklıdır. Türkiye Cumhuriyeti'nin bununla ilgili ilk tecrübesi söz konusu olan 23 Nisan 1921 tarihli meclis toplantısıdır. Ulusal bayramlara ilişkin ilk tartışma Birinci Meclis'in bu toplantısında geçer. O dönemde Meclis’te iki grup vardır. Birinci grup Mustafa Kemal önderliğinde oluşturulan Anadolu ve Rumeli Müdafaa-i Hukuk Grubudur. İkinci grup ise buna muhalif olan İkinci Müdafaa-i Hukuk Grubudur. Söz konusu tarihte, birinci grubun TBMM'nin açılış tarihi olan 23 Nisan'ın ulusal bayram ilan edilmesi teklifine ikinci grup, "Bu gibi bayramlar milletin kalbinden doğar. Bunun dışındaki kabuller, gösterişte kalır ve milletin maneviyatını desteklemez." görüşüyle karşı çıkarlar. Aslında bu tartışmanın alt katmanında laik 
olan Birinci Grup ile tutucu olan ve gelişmeler karşısındaki huzursuzluğunu bayram örneğinde olduğu üzere dolaylı yollarla dile getiren İkinci Grubun çatışması vardır (Özbudun, 1997, s. 139141). Bu tartışmaların sonunda 23 Nisan tarihi, ulusal bayram olarak " 23 Nisanın Millî Bayram Addine Kanun"u ile kabul edilir (Bolat, 2012, s.39). Yani kuruluştan bir yıl sonra, 23 Nisan'ın mücadeleyi meşrulaştırmaya yönelik olarak "Hâkimiyet-i Milliye Bayramı" adıyla millî bayram olması kararlaştırılır. Fakat 23 Nisan'ın bayram olarak kabul edilmesi ile ilgili yasa tasarısı, 2 Mayıs 1921'de kabul edildiği için, 1921 yılında 23 Nisan bayram olarak değil tezahürat şeklinde kutlanmıştır. Mustafa Kemal Paşa, Meclisin balkonundan yanında bulunan milletvekilleri ile birlikte halk1, askerleri ve öğrencileri selamlamıştır (Bolat, 2012, s.40).

23 Nisan tartışmalarının aksine, 29 Ekim'in ulusal bayram kabul edildiği TBMM'nin 19 Nisan 1925 tarihli toplantısı tartışmasız kapanmıştır. Fakat bu toplantıda "uygar ulusların kendilerine tek bir günü ulusal bayram olarak kabul ettikleri ve başka ulusal ve dinsel günler bulunsa da ancak o gün ulusal törenler yapıldığından" hareketle, Fransa'nın 14 Temmuz, ABD'nin 24 Temmuz günleri örnek verilerek Türkiye Cumhuriyeti için bugünün 23 Nisan yerine 29 Ekim gününün ulusal bayram ilan edilmesi gerektiği belirtilmiştir (Özbudun, 1997, s. 141142). Çünkü 23 Nisan devrimin bir aşamasıdır. Devrim, Cumhuriyetin ilanı ile tam olmuştur (Bolat, 2012, ss.66-67).

Meclis' in kurumsallaşması amacıyla icat edilen bu bayram, erken Cumhuriyet yıllarında "Çocuk Bayramı/Çocuk Haftası" etkinlikleriyle iç içe geçmiştir. Nedeni ise, siyasal iktidarın denetimindeki bir hayır kurumu olan "Himaye-i Etfal Cemiyeti"nin 1927 yılında almış olduğu bir kararla, 23 Nisan gününü Çocuk Bayramı; 1929 yılında ise 23-30 Nisan günleri arasını, "Çocuk Haftası" olarak kabul etmesidir (Aslan, 2011, s. 59-60). Birinci dünya savaşının yarattığı tahribat sadece toprak kaybı, ekonomik çöküntü gibi alanlarda kalmamış nüfus yapısını da değiştirmiştir. Kültürel bellekte çokça örneği olan ağıtlarda aktarıldığı üzere yetişkin, genç ve çocuk yaşta sayılan birçok erkek bu savaşta hayatını kaybetmiş̧tir. Geride kalan çocuklar ise kalkınmayı sağlayacak güç ve iradeye sahip olmaları bir yana trajik bir durumda kalmışlardı. Gerekli iç dinamizmin sağlanabilmesi için gerekli olan kuvvet o günün çocuklarında olmalıydı ama onlar da perişan durumdaydılar. Bu yüzden geride kalan çocukların maddi ve manevi olarak yetiştirilmesi gerekiyordu. İşte "Himaye-i Etfâl Cemiyeti" ilk olarak İstanbul'da 1917 yılında savaşta zor durumda kalan çocukları korumak amacıyla kurulmuş, ardından 1921 tarihinde Ankara'da kurumsallaşarak faaliyetlerine devam eden bir cemiyete dönüşmüştür. Bu cemiyetin 23 Nisan tarihinde çocuklara yardım kampanyaları düzenlemesi sonucunda 23 Nisan, dönemin kamuoyunca Hâkimiyet-i Milliye Bayramı olmaktan çok, Çocuk Bayramı olarak biliniyordu. Hâkimiyet-i Milliye bayramının adı 27 Mayıs 1935'te çıkartılan kanunla "Ulusal Egemenlik Bayramı" şeklinde Türkçeleştirildi. Çocuk Bayramı'nın bayram olarak ilan edilmesi ve kanunlaştırılması 19.03.1981 tarihli 2429 sayılı "Ulusal Bayram ve Genel Tatiller Hakkında Kanun” ile gerçekleşmiştir. Millî Hâkimiyet Bayramı'nın önüne resmî olarak eklenen Çocuk Bayramı ibaresiyle 23 Nisan Ulusal Egemenlik ve Çocuk Bayramı olarak yeniden adlandırılmıştır ve bu isimle kutlanmaya devam etmektedir (Saban, 2019, s. 204).

Esasında Türkiye Cumhuriyeti resmî olarak kutlanan bayramlar açısından zengin bir listeye sahiptir. $\mathrm{Bu}$ bayramları tarihsel gelişimleri bakımından olduğu kadar sosyolojik ve folklorik bir bakış açısıyla incelemek de bir zorunluluktur. Bu incelemelerde yazılı ve sözlü tarih araştırmaları birbirinden farklı bilgiler edinmemizi sağlar. Yazılı kaynaklar, millî bayramların morfolojisine, gelenekselleşmiş kutlanış kalıplarına ve bayram münasebetiyle verilen nutukların genel söylemlerine dair enformatik bilgi verir. Sözlü tarih ise bayram teması etrafinda toplanan anlatılar bütününden çıan ve bayramın toplumsal belleğimizde ne anlam ifade ettiğine dair bilgiler içerir (Öztürkmen, 1996a, ss.29-30). Yazılı ve sözlü tarih ekseninde ve sosyolojik, folklorik bakış açısıyla incelendiğinde millî bayramların ortak deneyim, beklenti ve eylem mekânlarından bir sembolik anlam dünyası yaratarak ulusal hareketlerin anımsanmasını ve insanların birbirine bağlanmasını sağladıkları görülecektir. Bu bağın oluşmasında toplumsal anımsama ilk şarttır. 
Bayramlara dönük toplumsal anımsamanın gerçekleşmesi için bayramların bazı işlevlere sahip olmaları gerekir. Bütün bayramlarda ortak olduğu üzere 23 Nisan Ulusal Egemenlik ve Çocuk Bayramının sahip olduğu işlevler toplumsal anımsamayı kolaylaştırmaktadır. 23 Nisan başta olmak üzere bayramlar bir folklor alanı olarak bazı işlevlere sahiptirler. Durkheim gibi sosyologların öncülük ettiği işlevselcilik eksenli çalışmalarda folklorun kültürde oynadığı rol üzerinde yoğunlaşılarak, folklorun sosyal kurumları sürdürmeye nasıl yardım ettiği tespit edilmeye çalışılır (Dorson, 2011, s. 33). W. Bascom'a göre folklorun dört temel işlevi vardır. Buna göre folklorun ilk işlevi eğlencedir. İkinci işlevi, kültürün onaylanması ve ritüelleri gözlemleyen ve icra edenlerin ritüellerinin ve kurumlarının doğrulanmasıdır. Folklorun üçüncü işlevi, bireylerin kültürel eğitimidir. Folklorun dördüncü işlevi ise kabul edilmiş davranış örüntülerini sürdürmesidir (Bascom, 2014, ss. 78-81). Buna göre folklorun ilk işlevi hoş vakit geçirme eğlenme ve eğlendirmedir. Folklorun değerlere, toplum kurumlarına ve törelere destek vermesi onun ikinci işlevidir. Bu işleve göre folklor içinde yer aldığı kültürdeki icraları yapanları ve bu icraları seyredip dinleyenleri, söz konusu kültürdeki ritüellerin toplumsal kurumlarını ve değerlerini doğrulayıp onaylamaktadır. Üçüncü işlev, kültürün gelecek kuşaklara aktırılarak bireylerin eğitilmesi işlevidir. Folklorun taşıdığı bilgiler tarihsel olarak gerçek ve öğretimleri son derece önemli olarak kabul edilir. Folklorun son işlevi toplumsal ve kişisel baskılardan kurtulmak için bir kaçıp kurtulma mekanizması olmasıdır. Bu işlevde kabul edilmiş davranış kalıplarına uygun davranıyor olmak ve bu yolla da meydan gelen toplumsal ve kişisel baskılardan kaçıp kurtulmayı sağlamaktır (Çobanoğlu, 2005, ss. 235-236). Bu işlevlerin yanı sıra son dönem çalışmalarda bu tür folklor ürünlerinin "politik işlevler"e de sahip oldukları kabul edilmektedir.

$\mathrm{Bu}$ işlevler doğrultusunda 23 Nisan Ulusal Egemenlik ve Çocuk Bayramının toplumsal anımsamayı gerçekleştirebilmesi için söz konusu işlevlere sahip olması gerekir. Bu işlevlerin en başında politik işlev gelir. 23 Nisan Ulusal Egemenlik ve Çocuk Bayramı da teşekkülü ve birden fazla değeri kendinde barındırmasından hareketle toplumsal anımsamanın gerçekleşmesi için önemli bir örnektir ve farklı yön ve özellikleriyle bazı politik işlevlere sahiptir. Bu politik yönlerin ilki millî irade vurgusudur. Uyanış hareketiyle başlayan süreç, TBMM'nin kurulmasıyla bir sembolik anlam alanı yaratarak ulusa ve uluslararasına irade değişikliğine gidildiğinin haberini vermiş olur. Millî Mücadele olarak taçlandırılan bu süreçte yaşanılanların unutulmaması ve anımsanması için millî bayram olarak belirlenmesi, toplumsal anımsamanın uluslaşma yolundaki önemini ve hâkim iradenin ihtiyaç hissettiği desteği verdiğini gösterir. TBMM'nin kuruluşunun bir bayram olarak kabulü mevcut dönemde millî iradeye ve yeni rejime geçerlilik kazandırma endişesi taşıyorken, gelecek nesillere toplumsal anımsama için görev yüklemekteydi. Savaştan kendi iç dinamikleri ile kurtulan ve yeniden inşaya başlayan Türkler, 23 Nisan'ın bayram olarak kabulü ile gelecek nesle yaşanılan zorlukların üstesinden nasıl gelindiğini anımsatarak bir ivme kazandırmak arzusunda idiler.

23 Nisan bayramı politik olarak siyasi iktidarın meşruiyeti dışında ayrıca toplumsal dayanışma ve düzeni sağlamada ve sürdürmede, millî karakteri güçlendirmede ve halkın eğitilmesinde de önemli işlevler üstlenmiştir (Bolat, 2012, s.8). Politik işlevlerin amacına ulaşması için siyasal iktidar, bu bayramları resmî tören olarak icra edilmesini istiyordu. Zira Türkiye Cumhuriyeti'nin resmî törenleri en ince ayrıntılarına dek, kanun, yönetmelik ve protokollerle belirlenmiş, denetimli, her türlü kendiliğindenlik ifadesine kapalı, düzen ve disiplini ön planda tutan, toplumsal hiyerarşiyi vurgulayan gösterilerdir. $\mathrm{Bu}$ törenlerde devlet görevlilerinin tören alanına giriş sırası, oturacakları yerler, tebrikleşme hiyerarşisi, törene katılacakların kılık kıyafetleri, geçitlerdeki sıralama, ışıklandırmanın nasıl olacağı, Atatürk anıtına yerleştirilecek çelenklerin önem sırasına göre getirilişi, taşınma ve yerleştiriliş biçimi, bayrağın evsafı, göndere çekiliş şekli ve diğerleri en ince ayrıntısına kadar protokol ve yönetmeliklerle belirlenmiştir (Özbudun, 1997, s. 153-154). Her ne kadar çocuk bayramı olsa da bayramın bu düzlemde kutlanması politik olarak otokontrol yaratacaktı. 
Politik işlevlerin belirdiği alanların biri de törenlerdeki resmigeçitlerdir. $\mathrm{Bu}$ resmigeçitlerin memleket varlıklarının hem o memlekette yaşayanlara hem de dışarıya karşı teşhir vazifesi görmesi, bu bayramların politik işlevlerindendir (Öztürkmen, 1996a, s. 32).

23 Nisan Ulusal Egemenlik ve Çocuk Bayramının toplumsal anımsama ile ilintili önemli bir diğer özelliği anımsaması istenenlerin öncelikle çocuklar olmasıydı. Bu millî bayramın ismine politik olarak "çocuk"un eklenmesi ile idealleştirilmiş bir "Türk Çocuğu" tipi yaratılmak istenmiştir. 23 Nisan sembolik olarak sağlıklı ve üretken bir nüfus/ulus inşasında uygulanan çocuk merkezli refah siyasetinin görselliğini dışa vurmaktaydı. Nüfusu çoğaltmanın, ruh ve vücut bakımından sıhhatli bir ulus yaratmanın öncelikli yolu, çocukları himaye etmekten geçiyordu (Aslan, 2011, s.82). Himaye edilen çocuklara Millî Mücadele dönemi, dönemin travmaları, uluslaşma süreci ve yeni hikâye bu bayram aracılığıyla anımsatılmalıydı. Bu yüzden Türk kültüründe bir örneği belki de sadece yağmur yağdırma törenlerinde olduğu üzere çocuklar törenlerde başrolde idiler. Şiirler okuyan, çeșitli gösteriler yapan çocukların, bu bayramın kazanımlarını anımsamaları hedeflenmekteydi. Yeni hikâyenin başrolü çocuklar idi ve Atatürk'ün ifadesiyle "onu yaşatacak ve yükseltecek olanlar" yine çocuklar ve gençlerdi. 23 Nisan Bayramı ile çocuklardan kazanımları tefekkür edip tezekküre dönüştürmeleri bekleniyordu. Atatürk'ün "Türk çocuğu ecdadını tanıdıkça daha büyük işler yapmak için kendinde güç ve kuvvet bulacaktır" söylemiyle ilintili olarak tefekkür edilmesi istenen değerlerin başında vatanlaştırma, uluslaştırma süreci ile atalarının sergilediği fedakârlıklar gelirken tezekküre döküleceklerin başında ise vatanperverlik doğrultusunda istiklale sahip çıkmak ve istikbale yön vermek geliyordu.

23 Nisan Ulusal Egemenlik ve Çocuk Bayramının toplumsal anımsamayı sağlayan ikinci işlevi kültürün aktarımını sağlamasıdır. Bayramların en belirgin özelliği icracıları, dinleyicileri/izleyicileri ve icra mekânlarını kimlikli hale getirmeleridir. Kimlikli hale getirmede en önemli husus binlerce yıllık deneyim ve birikimle belirginleşen kültürü yaygınlaştırmak ve belirlediği yazılı/yazılı olmayan kurallarla hayatı devam ettirmektir (Çelepi, 2017, s.393). Kültürel yapılanmanın ve tabakalaşmanın birçok unsuru ve evresi, 23 Nisan Ulusal Egemenlik ve Çocuk Bayramında yaşatılarak aktarılır. Bayramdaki icralar, Türk kültüründen taşıdığı izler, sürekli olarak "millî" değere yaptığı göndermeler, toprak ve vatan hassasiyeti, atalarla ilgili saygı tamamen Türklerin Eski kültürlerindeki kült tasarımları ile ilgilidir. Bu bağlamda bu bayram içindeki ritüelistik davranışlar ve bunların kökenleri, Türk kültürünün tarihsel yolculuğu ve inşa sürecindeki katmanları hakkında ayrıcalıklı bilgiler sunar. Toplumsal anımsamayı hedefleyen 23 Nisan bayramı, kültürel ve zihinsel kodlamaların yaşamasına imkân vererek aynı anda hem geçmişi yaşamaya hem de geleceği inşa etmeye destek verir. Katılımcıların hepsi, bu bayramın kutlamalarına katılmakla yeni rejime destek vermenin yanında tarihî ve kültürel bir sorumluluğu yerine getirirler.

23 Nisan Ulusal Egemenlik ve Çocuk Bayramının toplumsal anımsama çerçevesinde bir diğer işlevi kültürel ve toplumsal kimliklerin inşasına destek olmasıdır. Belirli bir kültür ve toplum içerisindeki birey, kendisini çevreleyen evreni, bulunduğu toplumun kültürel simgeleri ve yorumları aracılığıyla tanımlayıp algılar. Bireyin mutlak anlamda biyolojik bir varlık olmaktan çıkıp bu evren içinde yaşamayı başarması, belli bir kültürün maddi ve manevi ögelerini öğrenmesi ile mümkündür (Özdemir, 2005, s. 339). Bu bağlamda bir kültür dairesine aidiyet son derece önemlidir. Toplumsal kimliklerin oluşumu kültürel kimliklerin aidiyet bilinciyle içselleştirilmesinin neticesidir. Toplumsal kimlikler, ortak bir simgesel sistemin kullanımı ile ulaşılan ortak bilgi ve belleğe katılıma dayanırlar. Burada önemli olan kelimeler, cümleler ve metinler değil, gelenekler, danslar, örnekler, işlemeler, giysiler, dövmeler, yeme ve içme, anttlar, resimler, coğrafyalar, yol ve sınır işaretleridir (Assmann, 2015, s. 149). Bayramların meşruiyeti kimlik inşasına katkı ile paraleldir. Bu meşruiyet biraz da her sınıftan insanın bu törenlere katılımında saklıdır (Öztürkmen, 1996a, s. 32). 23 Nisan Ulusal Egemenlik ve Çocuk Bayramı da sahip olduğu ortak simgesel sistemin kullanımı ile herkesin toplumsal kimliğinin inşasına destek olur. Toplumsal anımsama, söz konusu toplumsal kimliklerin neticesidir. 
Toplumsal anımsama ve toplumsal kimliklerin inşasındaki bu ilişkide, aynı tarihî belleğe sahip olmak son derece önemlidir. 23 Nisan bayramı ile ilgili sözlü tarih araştırmalarında bayramın tanımları arasında "tarihin başlangıcı, yeni milletin doğduğu gün, saadet devrinin açıldığı gün, hâkimiyetin temellerinin atıldığ1 gün" (Öztürkmen, 1996b, s.8) gibi ifadelerin yer alması toplumsal anımsamanın ortak tarihî belleğin oluşmasındaki işlevlerini gösterir.

Bayramların, yerel kimliklerin inşası ve korunması işlevini yerine getirebilmesi, hedef kitlenin kültürel eğitiminin gerçekleştirilmesine bağlıdır. Bireylerin, kültürel ve toplumsal kimliklere sahip olabilmeleri için kültürün eğitim işlevini yerine getirmesi gerekir. Bunun için her kültürel sistem içinde eğitim süreci yer alır. Eğitim sürecinin hedef aldığı kesim çocuklar ve gençlerdir. Kültürel belleğin aktarımında en son aşamada olan ve hep "alan/alıcı" pozisyonundaki bu kesimin yetişeceği / besleneceği kültürel ortam, küreselleşmenin ve tek tipleşmenin etkisiyle hızlı bir şekilde Türk kültürden uzaklaşmaktadır. Bu yaş aralığındaki bireyler, Türk kültür değerleri içinde yetiştirilmediği ve kendilerine Türk kültür dairesine sahip olmanın önemi hissettirilmediği sürece, kültürlerini yaşatmayı ve korumayı öncelemeyeceklerdir. Kültürel eğitimde önde gelen alanlardan biride bayramlardır.

Türkiye Cumhuriyeti kutladığı resmî törenleri ve millî bayramları eğitim açısından dönemselleştirmiştir. Nutuk'taki tarihsel anlatıya göre büyük bayram olarak kabul gören günlerin kronolojik sıraları şöyledir: İlk olarak 19 Mayıs 1919'da Atatürk Samsun'a çıkıyor. Ardından 23 Nisan 1920'de TBMM açılıyor. Daha sonra 30 Ağustos 1922'de Büyük Taarruz sona eriyor ve nihayetinde 29 Ekim 1923'te Cumhuriyet ilan ediliyor. Kronolojik olarak akış bu şekilde olsa da toplumsal bellekteki hâkim sıralama eğitimdeki akademik takvime göre yapılagelmiştir. Okullar açılmasıyla ilk olarak 29 Ekim kutlanır. İkinci dönemde ise 23 Nisan ve 19 Mayıs kutlamaları yapılrı ve okullar kapanır. 30 Ağustos'ta okullar kapandığından eğitim olarak öğrencilerin belleğinde etkili değildir. Yani millî bayramların kutlama günleri kendi diakronik zamanlarından çıkarılıp başka bir zaman dilimine, senkronik bir zamana aktarılırlar (Öztürkmen, 1996a, s.30).

Bir eğitim toplantısı olan 23 Nisan Ulusal Egemenlik ve Çocuk Bayramındaki eğitimle, çocuk kendisine biçilen rol gereği kültürü yaşayarak kültürel daire içerisine girer. Böylelikle kendisini de koruma altına alır. Çocuk, bu bayramda öğrendiklerinin neticesinde bilim, sanat, spor ve daha birçok alandaki faaliyetlerinde referanslarını kendi kültürel dinamiklerinden almayı öğrenir.

23 Nisan kutlamaları çocukluk teması üzerine kurgulanmıştır. Bu durum hem millî hem de bireysel geçiş törenlerine aynı anda referans verir. 23 Nisan "çocukluk", "hâkimiyet" ve "TBMM" gibi hatırlama motiflerine sahiptir. Bu üç kavram sözlü anlatılarda berrak bir imaja sahiptir. Bireysel anımsamalarda "Çiçek bayramı gibi bir bayramdı" ifadeleri yer alır. Başka bir anlatıda "Bu bayramın en canlı manasını, renk renk giyinmiş kelebekler gibi uçuşan çocukların neşelerinde bulduk." ifadeleri yer alır (Öztürkmen, 1996b, s. 9). Bu ifadeler, 23 Nisan'ın toplumsal anımsamadaki konumunu göstermesi açısından son derece önemlidir.

23 Nisan Ulusal Egemenlik ve Çocuk Bayramının işlevlerinden biri de katılımcıların bu törende hoşça vakit geçirmeleridir. Okunan şiirler, düzenlenen yarışmalar, yapılan geçitler, sergilenen temsiller katılımcıların eğlenmelerini sağlar ve bir sonraki bayrama katılımcı sayısını artırır. Katılımc1 sayısının artması toplumsan anımsamanın neticesidir.

23 Nisan bayramlarının kutlanmasında dönemler arasında farklılıklar yaşanabilir. Bu durum toplumsal anımsama ile doğrudan ilgilidir. Örneğin Cumhuriyet'in onuncu yılı olan 1933 yılındaki 23 Nisan kutlamaları diğer dönemlere göre çok daha özverili ve renkli kutlanmıştır. Resmî tatil gün sayısı ikiye çıkarılmış çocuklara özel eğlenceler tertip edilmiştir (Öztürkmen, 1996b, s.11).Ülke tarihindeki gelişmeler doğal olarak bayramların kutlanmasını da etkilemiştir. Çok partili döneme geçişte görülen fikir ayrılıkları, bayramların kutlanma şekillerini değiştirmiştir. Ülkedeki askeri darbeler, kutlamalardaki askeri yönü artırmıştır. Tarih ilerledikçe, bayramların sahip olduğu coşku kutlamalardaki tekdüzelikle beraber yavaş yavaş azalmıştır. Bu dönemsel farklılıklar bazen beklenmedik tepkiler doğurabilir. Örneğin 2020 yılında insan 
sağlığını tehdit eden Covid19 virüsü bayramların kutlanmasını etkilemiştir. Fakat beklenenin aksine, Covid19 tedbirleri altında kutlanan 2020'nin 23 Nisan Bayramı son yılların en güçlü kutlamaları arasında gösterilebilir. Bütün ülkenin belirlenen bir saatte ekran başında İstiklal Marşını okuması, ailelerin evlerini süslemeleri, büyük toplu konutlarda tedbirlere uygun büyük kutlamaların yapılması, gerektiğinde toplumsal anımsamanın devreye girerek 23 Nisan kutlamalarının okullardan ve resmî kurumlardan sıyrılarak tabana yayılabileceğini göstermiştir.

\section{Sonuç}

Toplumsal anımsama, toplulukların kendi kültürel belleklerini anımsamalarıdır. Anımsamayla beraber geçmişe yaşam şansı verilirken gelecek kurgulanmaya çalışılır. Toplumsal anımsama, yaşanılan anı anlamlı ve güçlü kılar. Genelde törenler özelde de bayramlar toplumsal anımsamanın gerçekleştiği en önemli alanlardır. Türklerin binlerce yıllık birikiminin ve ortak deneyimlerinin sonucu olan birçok bayramı vardır. Bu bayramların bir kısmı Milliyetçilikle birlikte batıdan başlayarak millî bayramlar şekline dönüşmüştür. Türk insanı da II. Meşrutiyet ile birlikte Millî Bayram olgusu ile tanışmıştır. 20. yüzyıldan itibaren de siyasi erklerin yönlendirmeleriyle icraat ve kazanımlara meşruiyet kazandırmak amacıyla millî bayramlar kutlanmaya başlamıştır. Bu kararlılıkla mücadele ruhu kutsanmış ve geleceğe bu kazanımların korunması salık verilmiş olur.

TBMM'nin kabul ettiği ilk millî bayram olan 23 Nisan Ulusal Egemenlik ve Çocuk Bayramı, bir halkbilgisi unsuru ve folklor alanı olarak birçok işleve sahiptir. Siyasal iktidara meşruiyet zemini kazandırmak, toplumsal düzeni sağlamada ve sürdürmede, millî karakteri güçlendirmede ve halkın eğitilmesinde roller üstlenmek, idealleştirilmiş bir "Türk Çocuğu” tipini yaratmaya çalışmak 23 Nisan bayramının politik işlevlerinden birkaçıdır. Bayramın sahip olduğu ortak simgesel sistemin kullanımı ile toplumsal kimliğinin inşasına destek olması önemli sosyal işlevlerindendir. Bir eğitim toplantısı olan 23 Nisan Ulusal Egemenlik ve Çocuk Bayramıyla çocuğun kendisine biçilen rol gereği kültürü yaşayarak kültürel daire içerisine girmesi ve bu bayramda tarihî ve kültürel bilgiler ile donanması 23 Nisan bayramının eğitim işlevidir.

Politik, kültürel, kimlik inşa etme ve eğitim işlevleriyle 23 Nisan Ulusal Egemenlik ve Çocuk Bayramı, millî irade ve arzulanan Türk çocuğu sembolizmiyle toplumsal anımsamanın gerçekleşmesini sağlar. Anımsaması istenen çocukların ve gençlerin, millî irade ve sonrasındaki Cumhuriyetin kazanımlarının tümünü böylelikle tefekkür edip içselleştirmeleri ve bunu tezekkür ederek bilim, sanat, spor ve daha birçok alandaki faaliyetlerinde referanslarını kendi kültürel dinamiklerinden almaları sağlanır. Bu bayram böylelikle istikbalin ve istiklalin korunmasında toplumsal anımsama işlevini yerine getirmiş olacaktır.

\section{Kaynakça}

Arslan, M. (2017). Başkurt Türklerinin Tarihî Destanı İdigey ile Moradım. İstanbul: Ötüken Yayınları.

Aslan, D. A. (2011). Cumhuriyet'in Törensel Meşruiyeti: Ulus-Devlet İnşa Sürecinde Millî Bayramlar (1923-1938) (Yayımlanmamış doktora tezi). Ankara Üniversitesi. Ankara.

Assmann, J. (2015). Kültürek Bellek, Eski Yüksek Kültürlerde Yazl, Hatırlama ve Politik Kimlik, (Tekin A. Çev.). İstanbul: Ayrıntı Yayınları.

Bascom R. W. (2014). Folklorun Dört İşlevi. Halk Biliminde Kuramlar ve Yaklaşımlar-2, (Çalış, F. Çev.) 71-87. Ankara: Geleneksel Yayıncılık.

Bolat, B.S. (2012). Millî Bayram Olgusu ve Türkiye'de Yapılan Cumhuriyet Bayramı Kutlamaları (1923-1960). Ankara: Atatürk Araştırma Merkezi Yayınları.

Connerton, P. (2014). Toplumlar Nasıl Anımsar?. (Şenel, A. Çev.). İstanbul: Ayrıntı Yayınları.

Çelepi, M.S. (2017). Türk Kültür Evreninde Toy/Denizli Örneği. Konya: Kömen Yayınları. 
Çelepi, M.S. (2019). Batı Anadolu Efsanelerindeki Millî Mücadeleyi Kült Merkezli Okumak. Söylem Filoloji Dergisi, 4(2), 374-396.

Çobanoğlu, Ö. (2000). Yapısal ve İşlevsel Bakımdan Geleneksel Bayramlar Bağlamında Nevruz Ve Hıdrellez. Türkbilig-Türkoloji Araştırmaları Dergisi, 1, 51-59.

Çobanoğlu, Ö. (2005). Halkbilimi Kuramları ve Araştırma Yöntemleri Tarihine Giriş, Ankara: Akçağ Yayınları.

Divanü Lûgat-İt-Türk, (1985), I, II, III. Cilt, (Atalay, B. Çev.). Ankara: Türk Tarih Kurumu Yayınları.

Dorson, R.M. (2011). Günümüz Folklor Kuramları, (Gürçayır, S. ve Özay Y. Çev.). Ankara: Geleneksel Yayınc1lık.

Eliade, M (2015). Dinler Tarihine Giriş. (Arslan Özcan, L. Çev.). İstanbul: Kabalcı Yayınevi.

Halbwachs, M. (2016). Hafizanın Toplumsal Çerçeveleri (Uçar, B. Çev.). Ankara: Heretik Yayınları.

Halbwachs, M. (2018). Kolektif Hafiza. (Barış, B. Çev.). Ankara: Heretik Yayınları.

https://sozluk.gov.tr/. Erişim tarihi 29.06.2020

İlhan, M. E. (2018). Kültürel Bellek Sözlü Kültürden Yazllı Kültüre Hatırlama. Ankara: DoğuBatı Yayınları.

Özbudun, S. (1997). Ayinden Törene / Siyasal İktidarın Kurulma ve Kurumsallaşma Sürecinde Törenlerin İslevleri. İstanbul: Anahtar Kitaplar.

Özdemir, N. (2005). Türk Ĕglence Kültürü, Ankara: Akçağ Yayınları.

Öztürkmen, A. (1996a). Millî Bayramlar: Şekli ve Hatırası-I. Toplumsal Tarih Dergisi, 28. 2936.

Öztürkmen, A. (1996b). Millî Bayramlar: Şekli ve Hatırası-II. Toplumsal Tarih Dergisi, 29, 613.

Rahman, A. (1996). Uygur Folkloru. (Yalçın, ve Emet Çev.). Ankara: Kültür Bakanlığı Yayınları.

Saban, G. M. (2019). Millî Kimliğin Oluşturulması Bağlamında 23 Nisan Ulusal Egemenlik ve Çocuk Bayramı (Yayımlanmamış doktora tezi). Hacettepe Üniversitesi, Ankara.

\section{ETİK ve BİLIMSEL İLKELER SORUMLULUK BEYANI}

$\mathrm{Bu}$ çalışmanın tüm hazırlanma süreçlerinde etik kurallara ve bilimsel atıf gösterme ilkelerine riayet edildiğini yazar beyan eder. Aksi bir durumun tespiti halinde Afyon Kocatepe Üniversitesi Sosyal Bilimler Dergisi'nin hiçbir sorumluluğu olmayıp, tüm sorumluluk makale yazarına aittir. 